\title{
Evaluating the Effectiveness of Distance Learning Physical Education for Disabled Students
}

\section{Evaluación de la eficacia de la educación física a distancia para estudiantes discapacitados}

\author{
Natalia Yu. Tarabrina \\ nata-tarabrina_mai@mail.ru \\ https://www.scopus.com/authid/detail.uri?authorld=57195302795 \\ https://elibrary.ru/author_profile.asp?id=805530 \\ https://orcid.org/0000-0003-1469-5010 \\ $\mathrm{PhD}$ in Biological Sciences, Associate Professor, Moscow Aviation Institute \\ (National Research University), Moscow, Russian Federation. \\ Tomasz Wilczewski \\ akademiaeps@gmail.com \\ https://orcid.org/0000-0002-8575-3751 \\ Senior Lecturer, Academy of Physical Education in Katowice, Katowice, Poland.
}

\begin{abstract}
Recibido: $1 / 09 / 21$
Aceptado: 5/11/21

\section{Abstract}

The article discusses the effectiveness of the application of the distance learning program at the level of the functional state and reserve capacities of the organism of students with disabilities: for 12 students of 17-19 years old with idiopathic structural scoliosis of II and III degrees of S-shaped type, engaged in a full-time program (stage I) and for the same students studying remotely (stage II), it was studied the functional indicators of the cardiovascular and autonomic nervous system, the function of external respiration, the tone of the paravertebral muscles of the back and neck, as well as indicators of strength and endurance. Then a comparison was made of the studied indicators of stages I and II. It is shown that distance learning has a negative impact on the health of students: hypertonicity of the muscles of the back and neck significantly increases almost twice (the most sensitive is the cervicothoracic region), there is a shift of autonomic tone by $10.73 \%$ towards sympathicotonia: heart rate blood pressure increased by $19.06 \%$ by $7.9 \%$, respiratory rate by $7.92 \%$, tidal and minute volumes by $17.8-20 \%$, respectively. At the same time, strength endurance and the level of performance decrease by $11.7 \%$. Such changes contribute to the tension of neurohumoral mechanisms of self-regulation, which leads to a decrease in the stock of functional reserves and significantly narrows the range of possible adaptive responses. It is shown that the informatization of the educational
\end{abstract}


system in the edu cational process of students with disabilities should be of a mixed type, where the traditional form of classes remains the leading one.

Keywords: discipline "Physical Education", distance learning, special medical group, cardiovascular system, respiratory system.

\section{Resumen}

El artículo discute la efectividad de la aplicación del programa de educación a distancia a nivel del estado funcional y reservas de capacidades del organismo de estudiantes con discapacidad: para 12 estudiantes de 17-19 años con escoliosis estructural idiopática de II y III grados de Tipo en forma de S, participando en un programa de tiempo completo (etapa I) y para los mismos estudiantes que estudian de forma remota (etapa II), se estudiaron los indicadores funcionales del sistema nervioso cardiovascular y autónomo, la función de la respiración externa, el tono de los músculos paravertebrales de la espalda y el cuello, así como indicadores de fuerza y resistencia. Luego se realizó una comparación de los indicadores estudiados de las etapas I y II. Se demuestra que la educación a distancia tiene un impacto negativo en la salud de los estudiantes: la hipertonicidad de los músculos de la espalda y el cuello aumenta significativamente casi el doble (la más sensible es la región cervicotorácica), hay un cambio de tono autonómico en un $10.73 \%$ hacia simpaticotonía: frecuencia cardíaca, la presión arterial aumentó en un $19,06 \%$ en un $7,9 \%$, la frecuencia respiratoria en un $7,92 \%$, los volúmenes tidal y minuto en un 17,8-20\%, respectivamente. Al mismo tiempo, la resistencia a la fuerza y el nivel de rendimiento disminuye en un 11,7\%. Tales cambios contribuyen a la tensión de los mecanismos neurohumorales de autorregulación, lo que conduce a una disminución en el stock de reservas funcionales y reduce significativamente el rango de posibles respuestas adaptativas. Se muestra que la informatización del sistema educativo en el proceso educativo de los estudiantes con discapacidad debe ser de tipo mixto, donde la forma tradicional de clases sigue siendo la protagonista.

Palabras clave: disciplina "Educación Física", educación a distancia, grupo médico especial, sistema cardiovascular, sistema respiratorio.

\section{Introduction}

Distance education (DE) "is provided using mix of educational technologies, in which mediated interaction of the student and the teacher is made independently from their location on the basis of pedagogically organized information technologies, firstly with the usage of telecommunication tools" (Andreev, 2012) is regulated by Federal Law of the Russian Federation "On Education in the Russian Federation" (Law of the Russian Federation N 273-FZ, 2012), by order of the Ministry of Education and Science of Russia "On the implementation of additional professional programs and with the usage of DE programs, electronic education and in online form" (Ministry of education and science of the Russian Federation, 2014) and also by GOST R 52653-2006 "Information and 
communication technologies in education. Terms and definitions" (National Standard of the Russian Federation, 2008).

Under distance educational technologies (DET) we understand "educational technologies, realized with the usage of informational and telecommunication technologies (ITT) with mediated (at distance) or not completely mediated interaction of the student and the teacher" (Andreev, 2012). The materially technical base for providing electronical education and DET is a telecommunication network, educational website and electronical librarian system.

As a rule, institutions of higher education make possibilities of DE mostly by using one of such platforms as MOODLE and/or Microsoft Teams (MT) (Terentieva, 2019). These platforms are functional and intuitively are easy for understanding, they allow listening to lectures online or in recording, receive and give tasks, take part in "live" seminars and practical tasks. Teachers and students of Moscow Aviation Institute (National Research University) (MAI) also interact on two platforms: LMS MAI ("learning management system"), development and support of which is controlled by electronical education management of MAI and Microsoft Teams (MT). LMS MAI was developed in 2006 and up to nowadays it has been through 6 modernizations, received intuitively understandable navigation, enriched actual content in connection with what it received the biggest spread. From the 2014-2015 academic year, a number of disciplines, including lecture course and practical exercises, were partially implemented in the form of DE, and from March 17, 2020 they were completely transferred to a distance format. However, implementation of DET in educational process, despite its actuality, still has not received proper development. The experience of DE successful usage in terms of teaching linguistics, economics and law is undoubtedly useful, however, it cannot be mechanically transferred into the educational process in all subjects without exception, especially for students with disabilities and disabled people.

Thus, there is the contradiction between the necessity of developing new educational models, integrating distance and traditional technologies and the lack of scientifically methodical base and technologies practical realization, which will allow moving to a new level of training that meets the requirements of modern society. The existence of these contradictions convinces us of given research problem.

Article's goal is to study the features of the implementation of information and communication technologies in the environment of $D E$ in aviation university for students with disabilities.

\section{Methodology}

Research was made on 12 students ( 6 boys and 6 girls) from MAI, with disabilities, in the age of 17-19. All these students have a diagnosis: idiopathic structural scoliosis of II and III degrees of S-shaped type (I, Il type according to King) (King et al., 1983). 
Surveys were made in three stages. At the first stage, the functional indicators of the cardiovascular system and the function of external respiration, changes in the tone of the paravertebral muscles of the back and neck, as well as power indicators, endurance and general physical performance of students with disabilities were studied. On the second stage we studied DE program impact on the same students, using ITT program. On the third stage there was made a comparison of studied indicators of the first and second stages.

In the research there were used methods of anthropometry (height meter, scales), dynamometry (hand-held dynamometer DRP-120, Russia), spirometry (dry portable spirometer SSP, Russia), pulsometry and tonometry (tonometer Omron M2 Basic (HEM 7121-RU), Japan), myotonometry (myotonometer NOVOTEST, Russia). Physical performance was estimated with the usage of a modification of the classic PWC170 test (Romanenko, 1999). The main endurance and maximum oxygen consumption (VO2 max) were defined, using Cuper test (Romanenko, 1999). The changes in the vegetative tone were judged by KerDE index (Romanenko, 1999).

Myotonometric examination was carried out in eight symmetrical paravertebral points: PC 29 - "hsin-shi" localized at the level of the C3 segment, V14 - "jue-yin-shu" located on the broadest muscle of the back (m. latissimus dorsi) at the level of the Th4 segment, V24 "qi-hai-shu", localized $5 \mathrm{~cm}$ lateral to the spinous process of the III lumbar vertebra and V29 - "chzhong-lui-shu", located at the level of paired holes on the anterior surface of the sacrum, the place where the anterior branches of the sacral spinal nerves exit (sacral foramina) (Luvsan, 1990). The tone was assessed by the resistance that the muscle has when the myotonometer probe is immersed in it according to the standard method (Ivlijeva et al., 2005). The magnitude of the tone is expressed in conventional units according to Shore (Ivlijeva et al., 2005). To measure the static endurance of the muscular groups of the trunk (back, abs, oblique muscles of the abdomen, etc.), the time of maintaining the posture in the supine position with fixation of the limbs was recorded (Romanenko, 1999). Dynamic strength was assessed by the number of understandings of the body from the supine position: on the back, abdomen and on the side with the partner fixing the legs (Romanenko, 1999). The calculations and graphic design of the data obtained in the work were carried out using the "STATISTICA - 10.0" software package and Microsoft Excel. The choice of a criterion for testing statistical hypotheses and measures of central tendencies was carried out using the Shapiro-Wilk test. Then, a pairwise comparison of the groups was performed using the parametric Student's test.

\section{Results}

The results of the conducted research indicate that classes with the use of ITT for students with disabilities in full-time and distance programs have a number of fundamental differences in most of the studied functional indicators of the body.

For studying changes' dynamics, we consider every stage separately. On the first stage, anthropometric data (body weight (BW)), its length and body mass index (BMI) in students

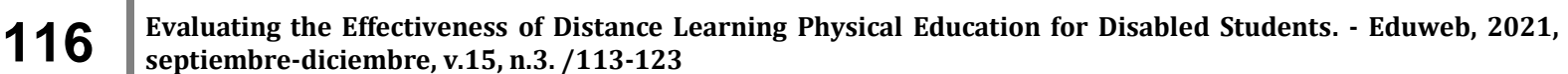


did not change significantly, however, functional indicators of the cardiovascular system (CVS) and respiratory function (RF) had a truly positive change.

Table 1.

Changes in indicators of anthropometry, cardio-respiratory system and physical working capacity of students with disabilities, students in full-time and distance learning programs.

\begin{tabular}{|c|c|c|c|c|c|c|}
\hline & \multicolumn{3}{|c|}{ Full-time form } & \multicolumn{3}{|c|}{ Distance form } \\
\hline Indicators & Before & After & $\Delta \%$ & Before & After & $\Delta \%$ \\
\hline (unit) & \multicolumn{6}{|c|}{ Anthropometric indicators } \\
\hline $\begin{array}{l}\text { Body length } \\
(\mathrm{cm})\end{array}$ & $1.76 \pm 0.5$ & $1.76 \pm 0.5$ & - & $1.76 \pm 0.5$ & $1.76 \pm 0.5$ & - \\
\hline BW (kg) & $\begin{array}{l}64.08 \pm 3.2 \\
2\end{array}$ & $\begin{array}{l}65.25 \pm 2.1 \\
2\end{array}$ & 1.82 & $\begin{array}{l}64.08 \pm 3.2 \\
2\end{array}$ & $\begin{array}{l}66.41 \pm 3.2 \\
0\end{array}$ & $3.63^{* *}$ \\
\hline $\mathrm{BMI}(\mathrm{g} / \mathrm{cm})$ & $\begin{array}{l}20.56 \pm 1.2 \\
3\end{array}$ & $\begin{array}{l}21.11 \pm 1.1 \\
4\end{array}$ & 2.67 & $\begin{array}{l}20.56 \pm 1.2 \\
3\end{array}$ & $\begin{array}{l}21.33 \pm 1.3 \\
8\end{array}$ & 3.74 \\
\hline \multicolumn{7}{|c|}{ Cardiovascular system } \\
\hline $\operatorname{HR}\left(\min ^{-1}\right)$ & $\begin{array}{l}85.15 \pm 2.3 \\
6\end{array}$ & $\begin{array}{l}74.32 \pm 2.6 \\
5\end{array}$ & $-\overline{12.71 *}$ & $\begin{array}{l}81.25 \pm 3.8 \\
6\end{array}$ & $\begin{array}{l}86.41 \pm 3.6 \\
1\end{array}$ & 6.35 \\
\hline $\begin{array}{l}\text { VIK } \\
\text { (conventional } \\
\text { units) }\end{array}$ & $1.09 \pm 0.06$ & $1.04 \pm 0.05$ & $-4.08^{*}$ & $1.08 \pm 0.06$ & $1.24 \pm 0.05$ & $14.81^{* *}$ \\
\hline DPs $(\mathrm{mmHg})$ & $\begin{array}{l}125.38 \pm 1 . \\
09\end{array}$ & $\begin{array}{l}120.26 \pm 1 . \\
20\end{array}$ & $-\overline{4}-58^{\star \star}$ & $\begin{array}{l}122.58 \pm 1 . \\
29\end{array}$ & $\begin{array}{l}126.66 \pm 1 . \\
21\end{array}$ & $3.32^{* *}$ \\
\hline $\mathrm{BPd}(\mathrm{mmHg})$ & $\begin{array}{l}78.00 \pm 2.3 \\
2\end{array}$ & $\begin{array}{l}71.25 \pm 2.2 \\
6\end{array}$ & $\begin{array}{l}- \\
8.65^{\star *}\end{array}$ & $\begin{array}{l}76.00 \pm 2.5 \\
8\end{array}$ & $\begin{array}{l}69.91 \pm 2.0 \\
6\end{array}$ & $-8.01^{* * *}$ \\
\hline $\mathrm{PP}(\mathrm{mmHg})$ & $\begin{array}{l}47.38 \pm 2.2 \\
2\end{array}$ & $\begin{array}{l}49.01 \pm 1.9 \\
9\end{array}$ & 5.21 & $\begin{array}{l}46.58 \pm 2.3 \\
4\end{array}$ & $\begin{array}{l}56.75 \pm 1.9 \\
5\end{array}$ & $21.83^{* *}$ \\
\hline \multicolumn{7}{|c|}{ Respiratory system } \\
\hline $\begin{array}{l}\mathrm{RR} \\
\text { (index/min) }\end{array}$ & $\begin{array}{l}18.95 \pm 1.3 \\
0\end{array}$ & $\begin{array}{l}18.23 \pm 1.2 \\
2\end{array}$ & -3.79 & $\begin{array}{l}17.75 \pm 1.5 \\
0\end{array}$ & $\begin{array}{l}19.83 \pm 1.4 \\
2\end{array}$ & $11.71^{* *}$ \\
\hline TV (ml) & $\begin{array}{l}260.60 \pm 30 \\
.12\end{array}$ & $\begin{array}{l}330.35 \pm 26 \\
.17\end{array}$ & $26.76^{*}$ & $\begin{array}{l}247.50 \pm 30 \\
.12\end{array}$ & $\begin{array}{l}230.25 \pm 28 \\
.27\end{array}$ & $-6.96^{\star *}$ \\
\hline MBV (ml/min) & $\begin{array}{l}4938.37 \pm 5 \\
64.26\end{array}$ & $\begin{array}{l}6022.28 \pm 5 \\
35.69\end{array}$ & $21.94^{*}$ & $\begin{array}{l}4418.33 \pm 5 \\
75.76\end{array}$ & $\begin{array}{l}4601.25 \pm 5 \\
92.59\end{array}$ & 4.14 \\
\hline VCL(ml) & $\begin{array}{l}2860.33 \pm 2 \\
5.98\end{array}$ & $\begin{array}{l}2990.16 \pm 2 \\
5.41\end{array}$ & $4.53^{*}$ & $\begin{array}{l}2900.83 \pm 2 \\
6.98\end{array}$ & $\begin{array}{l}2790.16 \pm 2 \\
5.41\end{array}$ & $-4.01^{* *}$ \\
\hline $\mathrm{PV}(\mathrm{l} / \mathrm{min})$ & $4.23 \pm 0.15$ & $4.80 \pm 0.35$ & $\begin{array}{l}13.47^{*} \\
*\end{array}$ & $4.13 \pm 0.17$ & $4.60 \pm 0.59$ & $11.38^{* *}$ \\
\hline $\mathrm{HI}(\%)$ & $.49 \pm 0.35$ & $4.07 \pm 0.46$ & -9.35 & $5.06 \pm 0.58$ & $4.67 \pm 0.46$ & -7.70 \\
\hline
\end{tabular}


Natalia Yu. Tarabrina, Tomasz Wilczewski.

\begin{tabular}{lllllll}
\hline $\begin{array}{l}\text { PWC170 } \\
\text { (kgm/min) }\end{array}$ & $457.33 \pm 10$ & $549.35 \pm 10$ & $20.12^{*}$ & $469.93 \pm 10$ & $509.53 \pm 11$ & $8.42^{* *}$ \\
\hline MOC ( $/ / \mathrm{min})$ & $32.15 \pm 1.6$ & $42.5 \pm 1.10$ & $32.19^{*}$ & $.76 .13 \pm 1.5$ & $34.03 \pm 2.1$ & $-5.81^{*}$ \\
& 9 & & & 7 & 0 & \\
\hline $\begin{array}{l}\text { Cuper test } \\
\text { (m) }\end{array}$ & $1728.65 \pm 9$ & $2350.15 \pm 9$ & $35.95^{*}$ & $1958.83 \pm 9$ & $1763.75 \pm 9$ & $-9.95^{\star *}$ \\
& 3.30 & 2.34 & $*$ & 5.33 & 9.94 &
\end{tabular}

Note: HR is the heart rate; VIK is the vegetative index KerDE; DPs is the systolic blood pressure; BPd is the diastolic blood pressure; PP is the pulse pressure; RR is the respiratory rate; TV is the tidal volume; MBV is the minute breathing volume; VCL is the vital capacity of the lungs; $\mathrm{PV}$ is the pulmonary ventilation; $\mathrm{HI}$ is the Hildebrant index; PWC170 is the physical performance; MOC is the maximum oxygen consumption; * $p \leq 0.05 ;^{* *}-p \leq 0.01 ;{ }^{* * *}-p \leq 0.001$ reliability of differences Student's t-test

As it is shown in the Table 1, DE format does not show the following significant changes: BMI and BM increased, DPs increased by $3.32 \%$ ( $p \leq 0.01$ ), and BPd decreased by $8.01 \%$ $(p \leq 0.01)$, at the same time, the sympathetic influence of the autonomic nervous system VIK - is traced: $1.24 \pm 0.05$ conventional units.

Before starting the experiment all students were dominated by the sympathetic circuit of regulation of the autonomic nervous system: vegetative index Kerdo - 1.09 conventional units. By the end of the first stage, the tone of the nervous system shifts by $4.08 \%(p \leq 0.05)$ towards the normotonicity of 1.04 conventional units. It has been shown that systematic physical training exercises significantly reduce HR by $12.71 \%(p<0.05)$, DPs and BPd by 4.58 and $8.65 \%$ ( $p \leq 0.05-0.01)$, respectively. RR decreases slightly, TV increases by $4.53 \%$ ( $p \leq 0.05)$, MBV and PV increase significantly by $21.94 \%(p \leq 0.05)$ and $13.47 \%$ $(p \leq 0.01)$, respectively.

There should be paid attention to the fact that in intact condition of all examined had indicators of respiratory function (RF) are much lower than normal people, because it is known that the presence of a costal-vertebral hump and deformation of the chest in idiopathic scoliosis lead to a weakening and asymmetric dysfunction of the muscles of the trunk, a decrease in the volume of the chest cavity, and the appearance of respiratory failure (Parkhomenko et al., 2013).

Comparison of relative changes (\%) of indicators of cardio-respiratory system and physical working capacity of SMG students, working in full-time and distance programs shows that the most significant differences are found on the indicators of HR, TV, MBV, physical performance and endurance.

In the result of research of the muscle tonus there was found that differences, which were received on the I and II stages in points are valuable ( $p \leq 0.05-0.001)$. There was fixed that classes in full-time form truly decreases muscle tonus in cervical spine from $10.01 \%$ to $16.38 \%(p \leq 0.001)$, in the thoracic spine from $22.81 \%$ to $25.84 \%$ ( $\leq \leq 0.001)$, in the lumbar spine symmetrically by $28 \%(p \leq 0.001)$, in sacral from $16.62 \%(p \leq 0.05)$ to $22.80 \%$ $(p \leq 0.001)$ (Table 2).

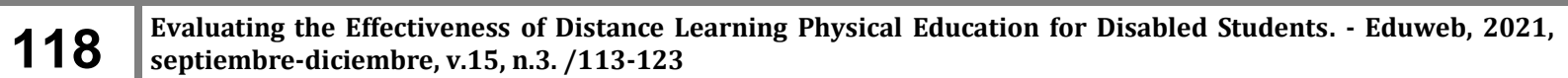


Table 2.

Changes in the tone of the muscles of the back and neck in students with disabilities enrolled in full-time and distance learning.

\begin{tabular}{|c|c|c|c|c|c|c|}
\hline & \multicolumn{3}{|c|}{ Full-time form } & \multicolumn{3}{|c|}{ Distance form } \\
\hline Indicators & Before & After & $\Delta \%$ & Before & After & $\Delta \%$ \\
\hline $\begin{array}{l}\text { PC } 29 \text { sinister } \\
\text { unit }\end{array}$ & $6.19 \pm 1.21$ & $\begin{array}{l}5.57 \pm \\
8\end{array}$ & $-\overline{10.01^{* * *}}$ & $\begin{array}{l}8.95 \pm 0.9 \\
1\end{array}$ & $\begin{array}{l}14.62 \pm 0 . \\
97\end{array}$ & 6325 \\
\hline $\begin{array}{l}\text { PC } 29 \text { dexter } \\
\text { unit }\end{array}$ & 6.5 & & - & $.04 \pm 1.0$ & $\begin{array}{l}18.12 \pm 0 . \\
41\end{array}$ & \\
\hline sinister & $\begin{array}{l}10.96 \pm 2.2 \\
7\end{array}$ & $\begin{array}{l}8.46 \pm 1 . .2 \\
3\end{array}$ & $22.81^{\star * *}$ & $\begin{array}{l}12.25 \pm 1 . \\
07\end{array}$ & & $51.02^{\star \star \star}$ \\
\hline V14 dexter unit & $\begin{array}{l}11.57 \pm 2.3 \\
8\end{array}$ & $\begin{array}{l}8.5 \\
4\end{array}$ & - & $\begin{array}{l}11.04 \pm 1 . \\
04\end{array}$ & $1 \pm 1$ & 15. \\
\hline sinister & $\begin{array}{l}17.07 \pm 2.8 \\
0\end{array}$ & $\begin{array}{l}12.26 \pm 2 . \\
12\end{array}$ & $28.17^{\star \star \star}$ & $\begin{array}{l}9.37 \pm 0.8 \\
4\end{array}$ & $\begin{array}{l}20.29 \pm 1 . \\
37\end{array}$ & $\begin{array}{l}11 \\
*\end{array}$ \\
\hline V24 dexter unit & $\begin{array}{l}17.88 \pm 2.9 \\
6\end{array}$ & $\begin{array}{l}12.86 \pm 2 . \\
12\end{array}$ & $-\overline{28.07^{\star * *}}$ & $8.62 \pm 0.7$ & $\begin{array}{l}16.45 \pm 5 . \\
79\end{array}$ & $90.83^{* * *}$ \\
\hline $\begin{array}{l}\text { V29 } \\
\text { unit }\end{array}$ & $4.15 \pm 1.21$ & $\begin{array}{l}3.46 \pm 1.2 \\
3\end{array}$ & $-16.62^{*}$ & $9.04 \pm 0.8$ & $\begin{array}{l}15.20 \pm 0 . \\
55\end{array}$ & ** \\
\hline V29 & $5.57 \pm 1$ & $\begin{array}{l}4.30 \pm 1.1 \\
82\end{array}$ & $22.80^{* * *}$ & $\begin{array}{l}7.16 \pm 0.4 \\
6\end{array}$ & $\begin{array}{l}15.00 \pm 0 . \\
68\end{array}$ & \\
\hline
\end{tabular}

Note: ${ }^{*}-p \leq 0.05 ;{ }^{* * *}-p \leq 0.001$ reliability of differences Student's t-test

While analyzing data of the II stage, there was found that DE does not reduce muscle tonus, but in contradiction, increases it: in the cervical spine from $63.35 \%$ to $100.44 \%$ $(p \leq 0.001)$, in the thoracic spine from $51.02 \%$ to $75.81 \%(p \leq 0.001)$, in the lumbar spine almost twice, and in the sacral spine from $68.14 \%$ to $109.49 \%$ ( $p \leq 0.001$ ) (Table 2). Such an increase in tone, in our opinion, is caused by insufficient motor activity, prolonged sitting at a computer desk in an uncomfortable position.

Comparison of relative changes (\%) indicators of muscle tone has shown that the most sensitive to changes were muscles of cervicothoracic and lumbar spine.

Analyzing changes of students' muscles strength endurance, we point out that on the I stage strength of both hands' wrists muscles has increased by $10 \%$ ( $p \leq 0.01$ ), static endurance of the back and abdominal muscles by $15.26 \% \quad(p \leq 0.01)$ and dynamic endurance of these muscles did not change significantly. The power endurance of the oblique muscles of the abdomen on the right (static and dynamic) did not have a significant increase, but on the left it increased by $7.86 \%$ and $22.55 \%$ ( $p \leq 0.01)$, respectively (Table 3 ). 
Table 3.

Changes in the indicators of static and dynamic strength endurance of the muscles of students with disabilities in full-time and distance learning programs.

\begin{tabular}{|c|c|c|c|c|c|c|}
\hline \multirow{3}{*}{$\begin{array}{l}\text { Indicators } \\
\text { Strenght of right hand } \\
\text { (kgf) }\end{array}$} & \multicolumn{3}{|c|}{ Full-time form } & \multicolumn{3}{|c|}{ Distance form } \\
\hline & Before & After & $\Delta \%$ & Before & After & $\Delta \%$ \\
\hline & $\begin{array}{l}20.22 \pm 1 \\
59\end{array}$ & $\begin{array}{l}22.39 \pm 1 \\
.30\end{array}$ & 10.73 & $\begin{array}{l}19.91 \pm 2 \\
.49\end{array}$ & $\begin{array}{l}17.58 \pm 2 \\
.30\end{array}$ & $\begin{array}{l}- \\
11.70^{*}\end{array}$ \\
\hline Strength of left hand (kgf) & $\begin{array}{l}18.31 \pm 1 \\
24\end{array}$ & $\begin{array}{l}20 . \\
.01\end{array}$ & ${ }_{* *}^{11.35}$ & $\begin{array}{l}17 . \\
.24\end{array}$ & $\begin{array}{l}14.6 \\
.01\end{array}$ & $-15.79^{*}$ \\
\hline SE of back muscles & $\begin{array}{l}35.25 \pm 4 \\
36\end{array}$ & $\begin{array}{l}40.63 \pm 4 \\
.25\end{array}$ & 15.26 & $\begin{array}{l}33.70 \pm 5 \\
.03\end{array}$ & $\begin{array}{l}27.78 \pm 4 \\
.52\end{array}$ & $\begin{array}{l}17.56^{*} \\
*\end{array}$ \\
\hline $\begin{array}{llr}\text { Dynamic } & \text { SE of back } \\
\text { muscles } & \text { (number of } \\
\text { times) } & & \end{array}$ & $\begin{array}{l}16.56 \pm 3 \\
34\end{array}$ & $\begin{array}{l}15.01 \pm 4 \\
.39\end{array}$ & -9.35 & $3 \pm 1$ & $8 \pm 1$ & $\begin{array}{l}- \\
16.33^{*} \\
*\end{array}$ \\
\hline $\begin{array}{l}\text { Static SE of abdominal } \\
\text { muscles (s) }\end{array}$ & $\begin{array}{l}25.40 \pm 2 . \\
90\end{array}$ & $\begin{array}{l}29 . \\
.15\end{array}$ & $\begin{array}{l}15.59 \\
* *\end{array}$ & $\begin{array}{l}22.39 \pm 2 \\
.92\end{array}$ & $3 \pm 3$ & $\overline{-}^{-}$ \\
\hline $\begin{array}{l}\text { Dynamic SE of abdominal } \\
\text { muscles (number of } \\
\text { times) }\end{array}$ & $\begin{array}{l}9.00 \pm 1.1 \\
5\end{array}$ & $\begin{array}{l}15.35 \pm 1 \\
.25\end{array}$ & 70.55 & $\begin{array}{l}8.58 \pm 1 \\
17\end{array}$ & $3 \pm 1$ & $\begin{array}{l}14.56^{*} \\
*\end{array}$ \\
\hline $\begin{array}{llr}\text { Static SE } & \text { of } & \text { oblique } \\
\text { abdominal } & & \text { muscles } \\
\text { (dexter) (s) } & & \end{array}$ & $\begin{array}{l}7.00 \pm 1.6 \\
2\end{array}$ & $\begin{array}{l}6.77 \pm 1 \\
54\end{array}$ & -3.28 & $\begin{array}{l}7.35 \pm 1 . \\
57\end{array}$ & \pm 1 & $\begin{array}{l}- \\
21.49^{*}\end{array}$ \\
\hline $\begin{array}{l}\text { Dynamic SE of oblique } \\
\text { abdominal } \\
\text { (dexter) (number of times) }\end{array}$ & $\begin{array}{l}6.35 \pm 1.2 \\
0\end{array}$ & $\begin{array}{l}7.08 \pm 1 \\
00\end{array}$ & 11.49 & $\begin{array}{l}5.58 \pm 1 \\
19\end{array}$ & $\begin{array}{l}6.08 \pm 1 \\
00\end{array}$ & 8.96 \\
\hline $\begin{array}{llr}\text { Static SE } & \text { of } & \text { oblique } \\
\text { abdominal } & & \text { muscles } \\
\text { (sinister) (s) } & & \end{array}$ & $\begin{array}{l}2.35 \pm 0.2 \\
6\end{array}$ & $\begin{array}{l}2.88 \pm 0 \\
70\end{array}$ & 22.55 & $\begin{array}{l}3.86 \pm 0 \\
60\end{array}$ & $\begin{array}{l}3.96 \pm 0 \\
58\end{array}$ & $2.59^{\star *}$ \\
\hline $\begin{array}{l}\text { Dynamic SE of oblique } \\
\text { abdominal } \\
\text { (sinister) } \\
\text { times) }\end{array}$ & $\begin{array}{l}4.96 \pm 2.8 \\
2\end{array}$ & $\begin{array}{l}5.35 \pm 2 . \\
01\end{array}$ & $7.86^{* *}$ & $\begin{array}{l}5.41 \pm 1 \\
01\end{array}$ & $\begin{array}{l}3.91 \pm 0 . \\
82\end{array}$ & $\underset{*}{27.72^{*}}$ \\
\hline
\end{tabular}

Note: $S E$ is the strength endurance, ${ }^{*}-p \leq 0.05 ;{ }^{* *}-p \leq 0.01$;

$* * *-p \leq 0.001$ reliability of differences Student's t-test

Data, which was received on the II stage, indicate the lack of classes' effectiveness in distance form, because by some indicators there is no growth. So SLH and SRH decreased by 11.7 and $15.79 \%$, respectively ( $p \leq 0.01$ ), SSEb and SSEa decreased by $15 \%(p \leq 0.01)$, and DSEb and DSEa by $20 \%(p \leq 0.01)$. A similar decrease was found in 120 Evaluating the Effectiveness of Distance Learning Physical Education for Disabled Students. - Eduweb, 2021,
septiembre-diciembre, v.15, n.3./113-123 
relation to the endurance of the oblique muscles of the abdomen: the gain was from 2 to $8 \%(p \leq 0.01)($ Table 3$)$.

\section{Discussion}

Advantages and logic of creating DET for providing it to students of different directions of preparation and specialties are the way of researching scientifically methodical character of different spheres: sociological, technological, humanitarian, medical, etc. (Tikhonov and Konovalova, 2020).

For the last five years' profile publications and collections of conference were shown as multiple scientific works in this problem. However, works, which prove the effectiveness of impact of DE on the students' health, is really small, and opinions of scientists are arguable.

More and more in foreign publications there is mentioned term "rethink education". In the work of Professor Andy Hargreaves there is a serious concern of the youth and teachers' physical health, who are on the stage of DE (Hargreaves, 2020).

Organization of economic cooperation and development (OECD) carefully estimates education technologies' advantages. The education sphere leader of OECD Andreas Schleicher pointed out the opinion that "educational systems have to pay attention the fact that technologies should not make the existing inequality in access and quality of education" (Schleicher, 2018).

Russian authors E.V. Lukina and N.E. Zhitnikova (Lukina and Zhitnikova, 2017) suppose that DE significantly makes the process of non-personal communication easier and get rid of many problems of psychological character, if the student has chronic diseases and/with disabilities. V.I. Yarmolinsky points on the possibility of distance monitoring of health condition of students with disabilities with the usage of "portable tools" of medical microelectronics for pulse control, blood pressure, heart rate variability, respiratory parameters, blood glucose concentration, blood oxygen saturation, etc. These tools are becoming more compact, handy and cheaper. There are developing mobile applications, providing reception and primary analysis of parameters, which are estimated by instruments and their transportation to distance server. Use of such instruments and applications completes the same educational function, increasing the knowledge circle and skills in questions of self-control of students with disabilities and teachers (Yarmolinsky, 2016).

The received data is agreed with previous researches and quite understandable from the point of view of muscular neurodynamics. A decrease in the tone of the paraverteral muscles of the cervicothoracic and lumbosacral spine, the elimination of local muscle hypertonia leads to the normalization of afferentations from the muscles in the chains of myocardial, myovascular and miorespiratory reflexes. The result of the harmonization of 
reciprocal relations of the muscles of the arms, chest and shoulder girdle is the improvement of their coordination and strength capabilities (Tarabrina, 2010; Polevoy and Strelnikowa, 2020).

Authors show that the distance course in organizationally contestable providing of educational process of students with disabilities must be based on the necessity of the students' activity and act on the principle of return connection with the following correction, when the teacher analyzes and methodically corrects, making teacher impact, in connection with the received data (Meinert et al., 2020; Polevoy, 2019).

We suppose that accent on theoretical and methodically practical information, formed on DE course, fostered student self-participation in organizing of the educational process, which had a positive but insufficient effect on the functional state and reserve capabilities of the body, and the level of health in general.

\section{Conclusion}

We suppose that DE, in professional preparation of students with disabilities of different specialties with the usage of any platform, also platforms Moodle and LMS, are not able to provide equal change to full-time classes. That is why traditional form of classes stays the leading one for students with deviations in the state of health. It is shown that students with disabilities studying distance learning have worse performance indicators of the cardiovascular system and function of external respiration decreases, increase in muscle tone causes spasm and edema of the periarticular tissues in the region of the back and neck, oxygen supply to the brain is disrupted, and the venous outflow of blood containing non-oxidized decay products decreases, muscles "acidify" and, consequently, decreased mental and physical performance. However, there should be pointed out that distance (inclusive) classes is not interchangeable for students with disabilities and disabled people, especially in the presence of complex, multiple diseases. The curriculum of MAI provides for the study of many course in a distance format with an emphasis on the theoretical and methodological block, therefore, we consider it logical to further develop and place programs for this category of students precisely on distance learning platforms.

\section{References}

Andreev, A. A. (2012). Formation and development of distance learning in Russia. Higher education in Russia, 10, 106-111.

Hargreaves, A. (2020). Moving: A Memoir of Education and Social Mobility. Bloomington: Solution Tree.

Ivlijeva, J., Vain, A., and Gapeyeva, H. (2005). Peculiarities of application of myometry for assessment of neuromuscular system of sportsmen. In Abstracts: 4th International Baltic Congress on Sports Medicine, Riga, Latvia, 22-23.

King, H. A., Moe, J. H., Bradford, D. S., and Winter, R. B. (1983). The selection of fusion levels in thoracic idiopathic scoliosis. Journal of Bone and Joint Surgery, 65(9), 1302-1313. 
Law of the Russian Federation N 273-FZ. Law of the Russian Federation on education in the Russian Federation, December 29, 2012, modified in 2020. http://zakon-obobrazovanii.ru/

Lukina, E. V., and Zhitnikova, N. E. (2017). Ways to optimize students' independent work on the subject of physical culture in higher education. Modern scientist, 9, 21-24.

Luvsan, G. (1990). Traditional and modern aspects of Eastern reflexology. Moscow: Science.

Meinert, E., Milne-Ives, M., Surodina, S., and Lam, C. (2020). Agile Requirements Engineering and Software Planning for a Digital Health Platform to Engage the Effects of Isolation Caused by Social Distancing: Case Study. JMIR Public Health Surveill, 6(2), e19297.

Ministry of education and science of the Russian Federation (2014). base.garant.ru. https://base.garant.ru/70706932 Letter from the Ministry of education and science of the Russian Federation on the direction of methodological recommendations for the implementation of distance learning technologies in the implementation of additional professional educational programs.

National Standard of the Russian Federation (2008). Information and communication technologies in education. Terms and definitions. National Standard of the Russian Federation, 52653-2006. http://docs.cntd.ru/document/1200053103

Parkhomenko, A. I., Melnichenko, E. V., Moroz, G. A., Bogenov, V. A., and Averkova, A. V. (2013). Conservative correction of ideopathic scoliosis with the remote effect of stabilizing. Crimea Journal of Experimental and Clinical Medicine, 3(4), 24-26.

Pinkovetskaia, I., Arbeláez-Campillo, D., Rojas-Bahamón, M., Novikov, S., \& Veas Iniesta, D. (2020). Social values of entrepreneurship in modern countries. Amazonia Investiga, 9(28), 6-13. https://doi.org/10.34069/Al/2020.28.04.1

Polevoy, G. G. (2019). Progress scoring system to motivate students for academic physical education classes. Theory and Practice of Physical Education, 9, 24-25.

Polevoy, G. G., and Strelnikowa, I. V. (2020). Complex control of coordination and speedpower abilities in fire-applied sports. Pedagogy of Physical Culture and Sports, 24(6), 310-315.

Rojas-Bahamón, M.J., Aguilar-Cruz, P.J., \& Arbeláez-Campillo, D.F. (2020). Curricular integration as a strategy to strengthen the educational process in public institutions in COVID-19 times. Revista Inclusiones, 7 (num Especial), pp. 233-241.

Romanenko, V. A. (1999). Motor abilities of a person. Donetsk: UKCentr.

Schleicher, A. (2018). World Class: How to Build a 21st-century School System. Paris: OECD Publishing.

Tarabrina, N. Yu. (2010). Health-improving correction of the physical condition of students with functional disorders of the cervical-thoracic spine. Pedagogics, psychology, medicalbiological problems of physical training and sports, 8, 86-89.

Terentieva, N. O. (2019). Features of distance education for masters of physical culture faculties. Information technologies and training tools, 69, 139-148.

Tikhonov, A. I., and Konovalova, V. G. (2020). Modern requirements for human resource management systems in russian companies. In Problems of Enterprise Development: Theory and Practice 18th International Scientific Conference. EpSBS: Social and Behavioural Sciences.

Yarmolinsky, V. I. (2016). High-tech self-monitoring. Science and innovation, 12, 28-29. 